\title{
Investigation of Salmonella spp. in Healthy and Diarrheic Cats
}

\author{
Ahmet ZENGINER $^{1 *} \quad$ Belgi DİREN SIĞIRCI ${ }^{1} \quad$ Baran ÇELIIK $^{1} \quad$ Arzu Funda BAĞCIĞíl ${ }^{1}$ \\ ${ }^{1}$ Department of Microbiology, Faculty of Veterinary, University of Istanbul, Aviclar 34320, Istanbul, Turkey
}

\begin{abstract}
Salmonellosis can be seen both in human and many species of animals. There are many studies on farm animals and especially in poultry farming in our country, but studies on companion animals, which have been a big part of urban life recently, are more limited. In this study, it is aimed to investigate the presence of Salmonella spp. with bacteriological and molecular methods (PCR) in cats. For this purpose, a total of 300 rectal swabs were collected from many different provinces of Istanbul, including healthy and diarrheic cats. For bacteriological examinations, swab specimens were seeded on selective media following the pre-enrichment step. Suspected colonies were purified and then identified by conventional methods. All swab specimens were also investigated by PCR for presence of Salmonella spp. specific gene regions. As a result of bacteriological investigations, no Salmonella spp. was isolated from any specimen. Positivity was detected in one specimen in PCR result. In conclusion, the isolation rate of Salmonella spp. is low when studies around the world are compared. Considering zoonotic characteristic of the agent, obtained results are very promising.
\end{abstract}

Keywords: Cat, Salmonella spp., culture, PCR

$\left[{ }^{*}\right]$ This study was summarized from PhD thesis of the first author.

\section{Sağlıklı ve İshalli Kedilerde Salmonella spp. Varlığının Araştırılması}

Öz: Salmonelloz gerek insan gerekse birçok hayvan türünde görülebilmektedir. Ülkemizde çiftlik hayvanlarında ve özellikle de kanatll yetiştiriciliğinde çok fazla araştırma olmakla birlikte son yıllarda şehir hayatının büyük bir parçası olmuş eşlikçi hayvanlardaki çalışmalar daha sınırlıdır. Bu çalışmada kedilerde Salmonella türlerinin varlığının bakteriyolojik ve moleküler yöntemler (PCR) ile araştırılması amaçlanmıştır. Bu amaçla, İstanbul'un farklı birçok ilçesinde, sağlıkl ve ishalli toplam 300 adet kediden rektal svab toplanmıştır. Bakteriyolojik incelemeler için, svab örneklerinin ön zenginleştirme aşamasını takiben selektif besiyerlerine ekimleri yapılmıştır. Şüpheli koloniler saflaştırıldıktan sonra konvansiyonel yöntemler ile identifikasyonları yapılmıştır. Tüm svab örnekleri aynı zamanda PCR ile de Salmonella spp. spesifik gen bölgelerinin varlı̆̆ yönünden incelenmiştir. Bakteriyolojik incelemeler sonucunda hiçbir örnekten Salmonella spp. izole edilmemiştir. PCR sonucunda bir örnekte pozitiflik saptanmıştır. Sonuç olarak çalı̧̧mada Salmonella spp. izolasyon oranı dünya genelinde yapılan çalışmalarla kıyaslandiğında düşük bulunmuştur. Hastalık etkeninin zoonotik özelliği de düşünüldüğünde sonuçlar umut vericidir.

Anahtar sözcükler: Kedi, Salmonella spp., kültür, PCR

$\left.{ }^{*}\right]$ Bu çalışma ilk yazarın doktora tezinden özetlenmiştir.

\section{INTRODUCTION}

Salmonella is a genus of Enterobacteriacea family and are Gram negative, non-spore forming, facultative anaerobic, catalase-positive, oxidase-negative and rodshaped bacteria (Kalambhe et al., 2016, Marks et al., 2011). In many animal species, including mammals, fish and birds, they are carried asymptomatically in intestines and gallbladder, and discharged continuously or intermittently in the stool. They are also found in mesenteric lymph nodules and tonsils (Kahya et al., 2013; Van Immersel et al., 2004). Environment, food and water are contaminated with discharge from intestines. (Kahya et al., 2013; Van Immersel et al., 2004).
Salmonellosis is seen as gastrointestinal infections especially characterized by acute diarrhea in cats and dogs. Clinical symptoms are very varied. The most important mode of transmission is fecal-oral transmission in cats and dogs. It is also stated that transplacental transmission, inhalative transmission and transcutaneal transmission by wounds during grooming can also occur (Kahya et al., 2013; Van Immersel et al., 2004).It has been reported that carrying birds and mice can play a role in infecting the cats (Philbey et al., 2009;) Clinical symptoms appear after 3-5 days following the transmission. Most cats and dogs recover spontaneously within 3-4 weeks. Fever, fatigue, vomiting, abdominal pain and diarrhea, loss of appetite are common symptoms. It can also cause pneumonia, abscess, meningitis, 
conjunctivitis, bacteremia/endotoxemia, multiple organ failure, septicemia, death, abortion and stillbirths. There are also asymptomatic cases out of them all (Carter et al., 2000; Hoelzer et al, 2011; Marks et al., 2011; Philbey et al., 2009; Stiver et al., 2003). Severity of the infection varies depending on the animal type, in cats and dogs. Variations such as heating, lighting, air changes, humidity and stress are important reasons of transmission of disease for cats and dogs living in crowded environments (Marks et al., 2011; Philbey et al., 2009; Van Immerseel et al., 2004)..

Cats and dogs remain to be the most preferred species as pet animals, and the incidence of salmonellosis in these animals is not known precisely, and thus the risks posed for humans remain uncertain (Philbey et al., 2009; Stiver et al., 2003; Van Immerseel et al., 2004). Cats are the animal group with high salmonellosis risk since they can also be fed outside as well as living only at home. For this reason, it was aimed to investigate the presence of Salmonella spp. in cats living in different life conditions in this study.

\section{MATERIAL and METHOD}

Specimens: In this study, stool specimens were collected by rectal swab method from a total of 300 cats at different ages and genders, 150 of which were healthy and 150 of which were diarrheic, living at home or outside of the houses in various districts of Istanbul between July 2013 and November 2014. Data including age, breed, environmental factors, feeding were obtained from the owners of the cats. Swabs were delivered to the laboratory by stuart carries medium with cold chain and stored at $-80^{\circ} \mathrm{C}$ until examined.

Of the cats examined, 167 cats were being fed at home and 133 cats were fed at work or in gardens having connection with outside. 166 cats were male and 134 were female. Two cats were elderly/geriatric (11 years and older) cats and 298 were adult (aged between 3 and 10years). 240 cats were hybrid, 20 cats were Persian, 30 cats were British shorthair, 10 cats were Scottish shorthair. Cats living at home were fed with dry food or home-made meals. Some of the other cats were fed with leftovers, dry good or unidentified food.

Bacteriological examination: For pre-enrichment, stool specimens were transferred into tubes containing $10 \mathrm{ml}$ buffered peptone water (BPW) and incubated at $41{ }^{\circ} \mathrm{C}$ for 18 hours. At the end of the incubation, $1 \mathrm{ml}$ of BPW was transferred to tubes containing $9 \mathrm{ml}$ of Tetrathionate Brilliant Green Broth (TTB) for selective enrichment and incubated at $37^{\circ} \mathrm{C}$ for 24 hours. At the end of incubation period, $2 \mathrm{ml}$ of the suspension was taken into microcentrifuge tubes and stored at $-80^{\circ} \mathrm{C}$ for PCR. A loopful of specimen from the residue suspension and transferred onto Xylose Lysine Desoxycholate Agar (XLD),
Brilliant Green (BG) Agar and MacConkey Agar. It was incubated at $37^{\circ} \mathrm{C}$ for 24 hours. (Kahya et al., 2013; WHO 2010, Van Immersel et al., 2004). At the end of incubation period, black colonies and black-centered ( $\mathrm{H}_{2} \mathrm{~S}$-positive) colonies with periphere changing from pink to red in XLD Agar; white and red colonies surrounded by red zones in BG Agar, colorless semi-transparent yellowish colonies in MacConkey Agar were evaluated as suspicious. These colonies were stained by Gram staining method and examined under microscope. Biochemical properties of Gram-negative, catalase-positive and oxidase-negative isolates were determined. For this purpose, urea test; indole test; Metil Red test; growth in Triple Sugar Iron Agar; multiplication in citrate agar; investigation of arginine dihydrolase, lysine decarboxylase and ornithine decarboxylase activity; OF test; gelatin hydrolysis test; phenylalanine deaminase test; growth in malonate broth and carbohydrate fermentation tests were performed (Quinn et al., 1994; WHO, 2010).

Polymerase Chain Reaction (PCR): One $\mathrm{ml}$ of specimens stored in TTB in deep freezing was transferred into a clean microcentrifuge tube and centrifuged for 4 minutes at $4600 \mathrm{xg}$. The supernatant fluid was poured out and the residue was homogenized with $1 \mathrm{ml}$ sterile physiological saline. It was centrifuged again at 4600x $\mathrm{g}$ for 4 minutes. The supernatant fluid was poured out and the residue was homogenized with $20 \mu$ l of distilled water. After incubated for 10 minutes at the heated blot set at $95{ }^{\circ} \mathrm{C}$, it was centrifuged at $18000 \mathrm{xg}$ for 3 minutes. Two $\mu \mathrm{l}$ of supernatant remained in PCR and used as template DNA (Eyigor et al., 2002).

Primer-139 (5' - GTG AAA TTA TCG CCA CGT TCG GGC AA-3') and primer- 141 (5'- TCA TCG CAC CGT CAA AGG ACC C-3') (Macrogen Inc., Republic of Korea) which are specific to invA gene region were used in PCR (Rahn et al., 1992).

PCR reaction mixture was prepared in total volume of $50 \mu \mathrm{l}$ with containing $5 \mu \mathrm{l}$ of $10 \mathrm{X}$ Buffer (without $\mathrm{MgCl}_{2}$ : and detergent, Tris-HCl, (NH4):SO4), 0,25 $\mu \mathrm{l}$ of FIREPOL ${ }^{\circledR}$ DNA Polymerase $(5 \mathrm{U} / \mu \mathrm{l}), 3 \mu \mathrm{l}$ of $\mathrm{MgCl}_{2}$ (25mM), $0,25 \mu \mathrm{l}$ of dNTPmix $(200 \mu \mathrm{M}), 1 \mu \mathrm{l}$ of forward and reverse primers for each ( 5 pmol), $2 \mu$ of template DNA, 37,5 $\mu$ l DNase-RNase free sterile distilled water (Chiu, 1996). S. typhimurium ATCC 14028 as a positive control; RNaseDNase free ultra-pure sterile distilled water was used as negative control.

Amplification was performed in total 30 cycles as 1 minute of pre-denaturation at $94^{\circ} \mathrm{C}, 30$ seconds of primer binding at $56^{\circ} \mathrm{C}, 2$ minutes of synthesis cycle at $72^{\circ} \mathrm{C}$ and 10 minutes of the last synthesis stage at $72^{\circ} \mathrm{C}$ (Chiu, 1996). Amplified PCR products were electrophoresed in $1.5 \%$ 
agarose gel. The band of $284 \mathrm{bp}$ was evaluated to be positive for Salmonella spp. (Kahya et al., 2013).

\section{RESULTS}

Bacteriological examination results: All collected specimens were inoculated into BPW for pre-enrichment and then TTB for selective enrichment. After passages to XLD, BG, MacConkey Agars from selective media, Salmonella suspected colonies were seen in the specimens collected from 13 healthy and 27 diarrheic cats. Biochemical tests were made for identification after cultures were purified. Salmonella spp. was not isolated according to the results of these biochemical tests.

PCR results: In the electrophoresis carried out following DNA extraction and DNA amplification procedures of 300 specimens, Salmonella spp. specific DNA was detected in one cat (Figure 1). The cat which was found positive with PCR was 10-year-old domestic female hybrid and healthy cat, fed with dry food. Even being a domestic cat, it was recorded that cat spent time on the balcony and hunted sparrows and doves coming for bait there.

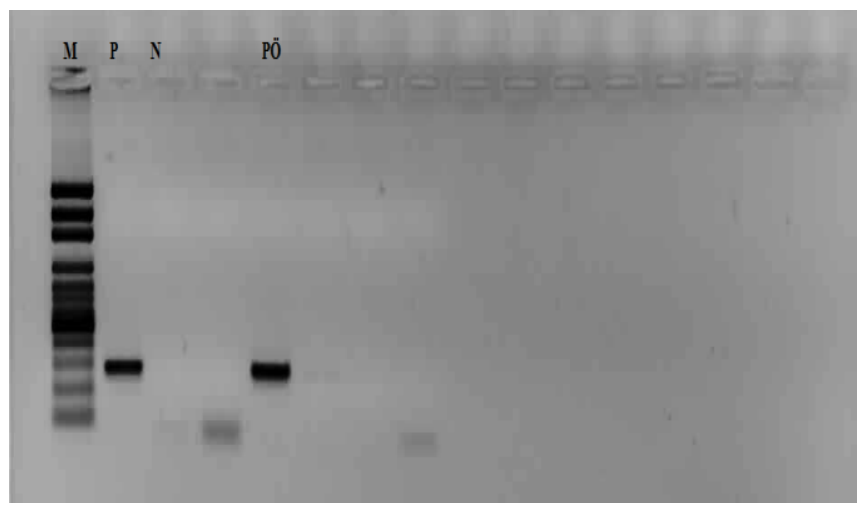

Figure 1. PCR results.

M: Marker, P: Positive Control (284 bp), N: Negative Control, PO: Positive Specimen (284 bp)

\section{DISCUSSION}

Salmonella, which is member of Enterobacteriacea family and causes diseases especially in the small intestine, is Gram negative and non-spore forming bacilli. In cats, salmonellosis is manifested as gastrointestinal infections characterized mainly by acute diarrhea. Clinical symptoms are very varied. Besides diarrhea, septicemia and death, there are also asymptomatic cases (Marks et al., 2011, Stiver et al., 2003, Hoelzer et al., 2011, Carter et al., 2000). Kozak et al. (2003) reported that salmonellosis frequently develops in latent forms in dogs and cats, and clinical findings vary according to the number of pathogens, immunity of the host and presence of other infections. The cat is the most preferred companion animal in urban life and incidence of Salmonella infections in these animals is unknown. Especially those that can freely circulate outside and reach or catch food in unknown qualities are potential candidates for the carriage of Salmonella species. Studies on salmonellosis in cats emphasize that carrier animals are very important in terms of transmission to humans (Stiver et al., 2003; Van Immerseel et al., 2004).

Carrier cats can pose a danger to susceptible individuals, such as children, elderly people, and immunosuppressed people (Van Immerseel et al., 2004;; Carter et al., 2000). Cats and dogs are the most preferred domestic animals to feed in our homes today. Because cats are in high risk of salmonellsis due to their lifestyles and there is no study carried out in our country on the presence of agent in cats, it is aimed to investigate the presence of Salmonella spp. in cats in various life conditions.

Salmonella serovars are found in the intestines and gallbladder in many animal species, mesenteric lymph nodes and tonsils (Hoelzer et al., 2011). Specimens were collected from various regions such as tonsils (Philbey et al., 2009), internal organs (Stiver et al., 2003; Philbey et al., 2009), nasal swabs (Kalammbhe et al., 2016) in the studies on agent prevalence but the most preferred specimen was stool (Hariharan et al., 2011; Philbey et al., 2009;). In this study, stool was chosen as examination specimen in order to determine the risk which might be caused in terms of prevalence in cats and on human health.

Hoelzer et al. (2011) reported that prevalence of salmonellosis in domestic cats was between $1-5 \%$ in the United States. Van Immerseel et al. (2004) reported that Salmonella spp. isolation rate in rectal swabs taken from the cats with different origins was $51.4 \%$ in the cats living in group; $8.6 \%$ in diseased cats and $0.36 \%$ in domestic cats. It was determined that detected isolates were S. typhimurium, $S$. enteritidis and $S$. bovismorbificans. In a study in northern Bavaria, stools of 2024 cats were examined and Salmonella serovars were detected in 39 (1.92\%) (Weber et al., 1995). In our country, salmonellosis in farm animals and poultry species have been emphasized, but studies on companion animals such as cats and dogs are limited. Bayram et al. (2016) found Salmonella enterica serovar Typhimurium phage type DT2 from a necropsy material of a dog (Bayram et al., 2016). Bagcigil et al. (2007) examined rectal swabs of 200 dogs and isolated agent from two dogs as $S$. typhimirium and S. enteritidis. Kocabiyık et al. (2006) received rectal swab specimens from 82 dogs and found a positive rate of $11 \%$. No study was reported about cats. In this study, stools of 300 cats in different age groups and different growth characteristics were investigated, Salmonella spp. was not isolated, and Salmonella spp. specific DNA was detected in a specimen of one cat.

Some characteristics of the specimen examined in the studies for Salmonella isolation affect isolation chance. For example, some researchers preferred fresh stool specimens (Carter et al., 2000; Kahya, 2014;) and some 
researchers preferred rectal swab specimens (Bagcigil et al., 2007; Kocabıyık et al., 2006; Van Immersel et al., 2004). In general, the common opinion of many of these studies is that freshness of the examined stool specimen is an important factor for increasing isolation chance. In addition, it is stated that agent prevalence is not continuous and the number of sampling is also important accordingly. Hill et al. (2000) investigated enteric zoonotic microorganisms, including Salmonella species, in stools of 199 cats and isolated $S$. typhimurium in two of them. Researches indicated that each cat had been examined only once and all of the stool specimens were not freshly examined or the specimens were not delivered to laboratory in a carrier environment may be among the reasons for low Salmonella isolation rate compared to similar studies. In this study, specimens were taken each cat only once and they were primarily stored in deep freeze. No Salmonella was isolated in any cat in the study and positive result was obtained in only one cat with PCR. This low rate is also considered to depend on the number of sampling and storage conditions. Another factor that might cause low positivity rate in PCR is that bile salt and $\mathrm{MgCl}_{2}$ in Tetrathionate broth can cause inhibition in PCR, as stated by Stone et al. (1994).

It is emphasized that age is an important factor in the incidence of Salmonella infections in many sources. The reason is that the immune system of young cats and dogs is not fully developed and the immune system over time is suppressed in older cats and dogs (Carter et al., 2000, Hariharan et al., 2011, Hill et al., 2000, Philbey et al., 2009 Van Immersel et al., 2004). Van Immersel et al. (2004) detected Salmonella spp. in $51.4 \%$ of the 4-month-old gregarious kittens and reported that incidence of infections in cats under 1 year of age is higher than that of elderly cats. Gow et al. (2009) investigated stools of clinically healthy 57 cats at 9 to 20 weeks of age in the United Kingdom, and isolated Salmonella spp. from one cat. They emphasized that Salmonella spp. can be detected without clinical symptoms in kittens. Kozak et al. (2003) obtained rectal swab specimens from a total of 200 animals - 187 dogs and 13 cats - from different age groups between 2001 and 2002. Salmonella spp. was detected in a four-month-old hybrid puppy and noted that puppy's contact with rodents and that the immune system is not yet fully developed are preliminary factors. Philbey et al. (2009) compiled the cases of Salmonella in the UK between 1955-2007. Between 1955 and 2007, Salmonella spp. were isolated in 100 cats. It was emphasized that $57 \%$ of the cats examined were the cats younger than six months of age. Hariharan et al. (2011) collected different specimens from 54 feral cats and investigated in terms of salmonellosis and did not isolate any agent. It was emphasized that all the cats were adult and did not indicate clinical symptoms. Salmonella spp. was not isolated in the specimens studies in this sudy, specific DNA was found $(0.33 \%)$ in one cat. Of the cats from which specimens were collected, 298 were adult (aged between 3 and 10 years) and 2 were elderly/ geriatric (11 years and older) cats. When the risk group of cats for salmonellosis is compared to the others, density in the least adult group is considered to be a factor decreasing isolation rate. Salmonella specific DNA was detected in a clinically healthy 10-year-old cat closed to elderly/geriatric group according to the classification in study.

The most important mode of salmonellosis transmission in cats and dogs is gastrointestinal transmission (Hoelzer et al., 2011; Kozak et al.,2003). Cats and dogs, as a carnivore, have a great risk of transmission because they often provide food requirement by hunting in nature. The risk of transmission of the agent is also high in cats and dogs fed with unidentified and/or contaminant foods and rodents (Carter et al., 2000; Hoelzer et al., 2011; Kozak et al., 2003). It is stressed that the incidence of infections in cats and dogs fed with raw bones and meats, called BARF diets, is higher, or that these animals are asymptomatic carriers. (Hoelzer et al.,2011; Mark et al., 2011). Clyde et al. (1997) detected Salmonella spp. in more than $90 \%$ of exotic cats in two different groups eating raw chicken meat and horse meat. Giving waste food or contaminated cat/dog foods to these animals is shown to be infection source in cats and dogs (Stiver et al., 2003). Hill et al. (2000) stated that the reason why enteric zoonotic agents were detected at lower rates in the study conducted on cats more than previous studies is that cats started to consume more over-cooked and processed foods with changes in nutritional practices depending on the developments in husbandry over the years. In this study, specimens were collected from 167 cats who live in houses or indoors and 133 cats who are connected to outside. $222(74 \%)$ of the cats were fed with dry food or cooked home meals. 78 cats were consuming both dry food and unidentified food. As stated in this study, cats which are raised outside are also fed with identified or dry food, especially for hygienic conditions today. This is also considered to be one of the reasons for the absence of agent isolation in this study study. Reducing the transmission rate of a zoonotic bacteria by such simple measurements can be interpreted as a positive situation. In this study, Salmonella spp. was detected in one cat. When details of the cat were seen, it was remarkable that it was a house cat feeding with dry food. This supports the views of Hoelzer et al. (2011), who report that dogs fed with raw foods are at risk, and the fact agent was found in animals feeding with commercial food shows that the only source of transmission is not row food.

There are studies in which culture and PCR are used together to investigate the presence of Salmonella spp. in different animal species. Ward et al. (2005) did not isolate the agent in their studies, but detected positivity in PCR in one specimen. They stated that the probability of isolation due to other contaminant bacterial strains is lower when cultivated from stool, and the chances of catching positive 
animals by PCR are higher. Similarly, Çarlı et al. (2001) and Kahya et al. (2013) found the advantages of PCR in detecting agent in poultry. Olivera et al. (2003) compared the standard isolation and post-culture PCR methods and found that the second method is more sensitive and shortens the time required for diagnosis. Maciel et al. (2011) compared culture and PCR method in asymptomatic animals together. Positivity was detected as $12 \%$ in culture and $31 \%$ in PCR. In this study, supporting the existing studies, no agent was isolated from specimens but Salmonella spp. DNA was detected in a specimen of cat by PCR following the culture. The reason why agent was detected in low rate by PCR might be bile salts in Tetrathionate fluid media used for culture, as suggested by some researchers (Stone et al., 1994), as well as low presence of agent in cats.

Salmonella spp. was not isolated in 300 cats which were investigated in this study, but specific DNA was detected in only one specimen. Isolation rates are not very high when studies around the world are analyzed. In our country, there is no study conducted on cats. Considering zoonotic disease agent, obtained results are very promising. 300 cats living in different environments and feeding with different food were examined and different media were used to increase isolation chance; in addition, specimens were analyzed with also culture-PCR suggested by many researchers for its sensitivity. It was seen that Salmonella transmission does not cause a significant risk according to these findings. However, detecting agent DNA in a clinically healthy, home cat shows the importance of hygienic rules.

\section{ACKNOWLEDGMENT}

This work was support by Scientific Research Project Coordination Unit of Istanbul University (Project numbers: 29877 and BEK-2016-21302). This study was present as a oral presentation in the $3^{\text {rd }}$ International VetIstanbul Group Congress 2016, May 17-20 2016, Sarajevo and as a poster presentation in $18^{\text {th }}$ International Veterinary Medicine Students Scientific Research Congress, İstanbul, Türkiye, 26-28 April 2016.

\section{REFERENCES}

Bagcıgil, A.F., İkiz, S., Dokuzeylül, B., Başaran, B., Or, E. \& Ozgur, N.Y. (2007). Fecal shedding Salmonella spp. in dogs. Journal of Vetarinary Medical Science, 69(7), 775-777.

Bayram, L.C. \& Aydın, F. (2016). An abdominal cavity abscess associated with Salmonella enterica serovar Typhimurium phage type DT2 in a dog: a case report. Veterinarni Medicina, 61,(5):272-278.

Carlı, T.K., Unal, C.B., Caner, V. \& Eyigör, A. (2001). Detection of Salmonella in chicken feces by a combination of tetrathionate broth enrichment, capillary PCR, and capillary gel electrophoresis. http://jcm.asm.org/.

Carter, M.E. \& Quinn, P.J. (2000). Salmonella infections in dogs and cats. In: Wray C., Wray A., eds. Salmonella in Domestic Animals, UK, Cabi Publishing, pp 231-244.

Clyde, V.L., Ramsay, E.C. \& Bemis D.A. (1997). Fecal shedding of Salmonella in exotic felids. Journal of Zoo and Wildlife Medicine, 28(2), 148-152.

Eyigor, A. \& Carli, K.T. (2003). Rapid detection of salmonella from poultry by Real-Time Polymerase Chain Reaction with Flourescent Hybridization Probes. Avian Diseases, 47:380-386.

Gow, A.G., Gow, D.J., Hall, E.J. \& Papasouliotis, K. (2009). Prevalance of potentially pathogenic enteric organisms in clinically healthy kittens in UK. Journal of Feline Medicine and Surgery, 11, 655662.

Hariharan, H., Matthew, V., Fountain, J., Snell, A., Doherty, D., King, B., Shemer, E., Oliviera, S. \& Sharma, R.N. (2011). Aerobic bacteria from mucous membranes, ear canals, and skin wounds of feral cats in Grenada, and the antimicrobial drug susceptibility of major isolates. Comparative Immunology, Microbiology and Infectious Diseases 24, 129-134.

Hoelzer, K., Switt, A.I.M. \& Wiedmann, M. (2011). Animal contact as a source of human non-typhoidal salmonellosis, Veterinary Research, 42, 34 doi:10.1186/1297-9716-42-34.

Hill, S.L., Cheney, J.M., Taton-Allen, G.F., John, M.S., Reif, S., Bruns, C. \& Lappin, M.R. (2000). Prevalence of enteric zoonotic organism in cats. Journal of the American Veterinary Medical Association, 216(5), 687-692. doi:10.2460/javma. 2000.216.687.

Kahya, S., Eyigör, A. \& Çarlı, K.T. (2013). Comparison of different sample types for Salmonella detection from chicken layer breeder flocks. Uludag University Journal of the Faculty Veterinary Medicine, 32(2), 19-24.

Kalambhe, D.G, Zade, N.N, Chaudhari, S.P, Shinde, S.V, Khan, W. \& Patil, A.R. (2016). Isolation, antibiogram and pathogenecity of Salmonella spp. recovered from slaughtered food animals in Nagpur region of Central India. Veterinary World, 6, 176181.

Kocabıyı, A.L, Cetin, C. \& Dedicova, D. (2006). Detection of Salmonella spp. in stray dogs in Bursa province, Turkey: First isolation of Salmonella corvallis from dogs. Journal of Veterinary Medicine B, 53, 194-196.

Kozak, M., Horososva, K., Lasanda, V., Bilek, J. \& Kyselova, J. (2003). Do dogs and cats present a 
risk of transmission of salmonellosis to humans? Brastil Lek Listy, 104(10), 323-328.

Maciel, B.M., Dias, J.C.T., Romano, C.C., Sriranganathan, N., Brendel, M. \& Rezende R.P. (2011). Detection of Salmonella enteritidis in asymptomatic carrier animals: comparison of quantitative real-time PCR and bacteriological culture methods. Genetics and Molecular Research, 10(4), 2578-2588.

Marks, S.L., Rankin, S.C., Byrne, B.A. \& Weese, J.S. (2011). Enteropathogenic bacteria in dogs and cats: diagnosis, epidemiology, treartment, and control. ACVIM consensus statement, Journal of Veterinary Internal Medicine, 25, 1195-1208.

Olivera, S.D., Rodenbusch, C.R., Cé, M.C., Rocha, S.L. \& Canal, C.W. (2003). Evaluation of selective and non-selective enrichment PCR procedures for Salmonella detection. Lett Appl Microbiol. 36(4), 271-21.

Philbey, A.W., Brown, F.M., Mather, H.A., Coia, J.E. \& Taylor, D.J. (2009). Salmonellosis in cats in the United Kingdom: 1955 to 2007. The Veterinary Record, 164(4), 120.

Quinn, P.J., Carter, M.E., Markey, B.K. \& Carter, G.R. (1994). Clinical veterinary microbiology. MosbyYear Book Europe, London, 221.

Rahn, K., De Grandis, S.A., Clarke,, R.C., McEwen, S.A., Galan, J.E., Ginocchio, C., Curtiss, R. 3rd. \& Gyles, C.L. (1992). Amplification of an invA gene sequence of Salmonella typhimurium by polymerase chain reaction as a spesific method of detection of Salmonella. Molecular and Cellular Probes, 6(4), 271-279.

Stiver, S.L., Frazier, K.S. \& Manuel, M.J. (2003). Septisemic Salmonellosis in two cats fed a rawmeat diet. Journal of the American Animal Hospital Association, 39, 538-542.
Stone, G.G., Oberst, R.D., Hays, M.P., McVey, S. \& Chengappa, M.M. (1994). Detection of salmonella serovars from clinical samples by enrichment broth cultivation-PCR procedure. Journal of Clinical Microbiology, 32(7), 1742-1749.

Ward, M.P., Alinovi, C.A., Couetil, L.L. \& Wu, C.C. (2005). Evaluation of a PCR to detect salmonella in fecal samples of horses admitted to a veterinary teaching hospital. Journal of Veterinary Diagnostic Investigation, 17, 118-123.

Weber, A., Potel, J., Schafer-Schmidt, R., Prell, A. \& Datzmann, C. (1995). Studies on the occurrence of Listeria monocytogenes in fecal samples of domestic and companion animals. International Journal of Hygiene and Environmental Medicine, 198, 117-123.

WHO. (2010). WHO global foodborne infections network laboratory protocol "Isolation of Salmonella spp. from food and animal feaces" $5^{\text {th }}$ Ed. June 2010.

Van Immersel, F., Pasmans, F., De Buck, J., Rychlik, I., Hradecka, H., Collard, J.M., Wildemauwe, C., Heyndrickx, M., Ducatelle, R. \& Haesebrouck, F. (2004). Cats as a risk for tranamission of antimicrobial drug-resistant Salmonella. Emerging Infections Diseases, 10(12), 2169-2174.

Received date: 31.01 .2018

Accepted date: 29.03 .2018

\section{*Corresponding author's:}

Vet. Hek. Ahmet ZENGINER

Department of Microbiology, Faculty of Veterinary, University of Istanbul, Avc1lar 34320, Istanbul, Turkey E-mail: ahmet_zenginer@yahoo.com 